\title{
Energy Dispersive X-Ray Spectroscopy of the Sohnari Member of Laki Formation from Southern Indus Basin of Pakistan
}

\author{
Muhammad Asif Noonari ${ }^{1,2}$, Surih Sibaghatullah Jagirani ${ }^{2,3 *}$, Huafeng Tang1, \\ Asghar A. A. D. Hakro², Ali Ghulam Sahito², Kaleemullah Jagirani²,4, \\ Shahid Ali Shaikh², Muhammad Dodo Jagirani2,3,5* \\ ${ }^{1}$ College of Earth Science, Jilin University, Changchun, China \\ ${ }^{2}$ Centre for Pure and Applied Geology University of Sindh, Jamshoro, Pakistan \\ ${ }^{3}$ Institute of Tibetan Plateau Research, Chinese Academy of Science, Beijing, China \\ ${ }^{4}$ Oil and Gas Development Company Limited, Islamabad, Pakistan \\ ${ }^{5}$ Department of Geography University of Sindh, Jamshoro, Pakistan \\ Email: *surih@itpcas.ac.cn, ${ }^{\star}$ mdjagirani@itpcas.ac.cn
}

How to cite this paper: Noonari, M.A., Jagirani, S.S., Tang, H.F., Hakro, A.A.A.D., Sahito, A.G., Jagirani, K., Shaikh, S.A. and Jagirani, M.D. (2021) Energy Dispersive X-Ray Spectroscopy of the Sohnari Member of Laki Formation from Southern Indus Basin of Pakistan. Open Journal of Geology, 11, 183-196.

https://doi.org/10.4236/ojg.2021.116011

Received: April 8, 2021

Accepted: June 7, 2021

Published: June 10, 2021

Copyright $\odot 2021$ by author(s) and Scientific Research Publishing Inc. This work is licensed under the Creative Commons Attribution International License (CC BY 4.0).

http://creativecommons.org/licenses/by/4.0/

\section{(c) (i) Open Access}

\begin{abstract}
This study determines the geochemical and depositional environment analysis of the sediments of the Sohnari Member of the Laki Formation, Northern Kirthar Fold Belt of Pakistan. The Energy-Dispersive-X-Ray Spectroscopy (EDS) technique is used for the detection of major elements and the effects of shifting depositional climatic conditions of six representative samples which were acquired from the Sohnari Member of the Laki Formation at Lakhra area, Sindh, Pakistan. The sedimentological studies clarify that the sediments the Sonahri Member are relatively immature and most migrated in clastic mode. The availability of Silica shows that the Member was formed due to biochemical precipitation and detrital mode and was deposited at a fast rate of sediment deposition under the fluvio-deltaic depositional system. This is also deduced that the rapid rate of sediment deposition might be created a reducing atmosphere and allowing for the mineralization of sulphur.
\end{abstract}

\section{Keywords}

Energy Dispersive X-Ray Spectroscopy, Geochemistry, Sohnari Member the Laki Formation, Northern Kirthar Fold Belt of Pakistan

\section{Introduction}

Sohnari member is the basal part of the Laki Formation which overlies the Ra- 
nikot group and the Lakhra Formation of the Lakhra area [1] and [2]. Its basal contact is with Ranikot Group and got is unconformable obvious and its upper contact is with chat member of Laki Formation [3] [4] [5] [6]. Our study is focused on a geochemical investigation of the Sohnari member of the Laki Formation to interpret its origin and climate (Figure 1). SM of the Laki Formation is also thought to be a distinct origin from the Lakhra Formation and the overlying Chat member. Due to different characters the Sonhari member (Figure 3). It is worth including the position from the Laki formation SM is a section of clastic sedimentary rock transported beginning the east also placed among the Chat member and the Lakhra Formation. The SM is known as basal Laki laterite and represents the very slight regression possibly a reduction in the rate of the sinking of the continental shelf in the Indian Shield of Indian Plate and the peat is accumulated very close to the sea level.

\subsection{General Geology of the Study Area}

Rocks exposed in the studied area are mainly composed of detrital and non-detrital sediment. The rocks exposed in the study area belongs to the Ranikot, [7] and [8], which is primarily made up of the Bara Formation (Middle Paleocene)

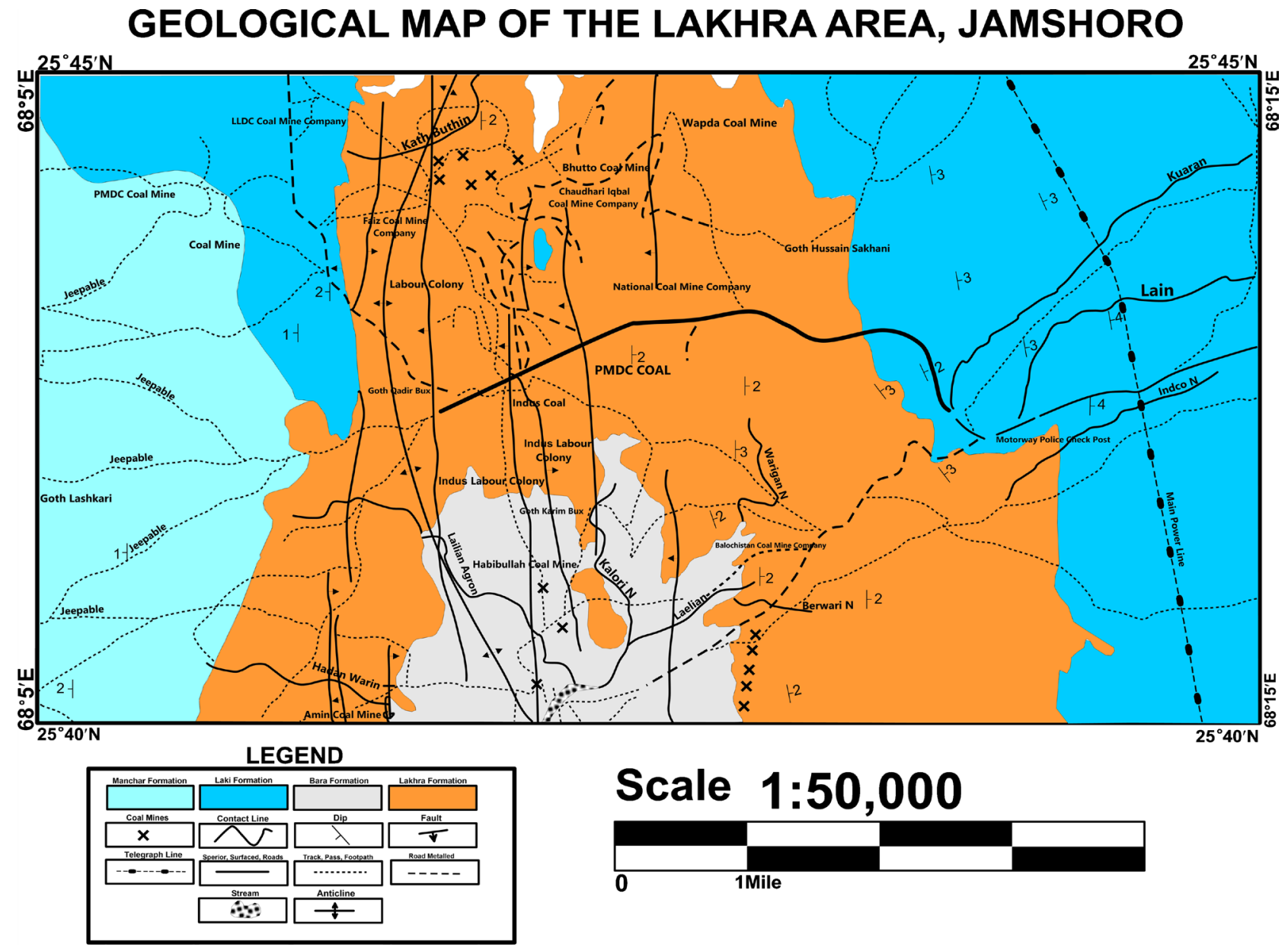

Figure 1. Geological map of the study area. 
Lakhra Formation (Late Paleocene), Sohnari, and Chat members of the Laki Formation (Early Eocene), Manchar Formation (Pliocene). These components contain shallow seas and floating sediments. Projected area is the Sohnari member that is chiefly composed of sandstone, nodular limestone, and lateritic clay, and gypsiferous shale of variegated colors including yellow, orange, red, maroon, rusty brown, and gray. Sandstone sometimes occurs in lenticular beds of variegated colors (Figure 2). Sandstone is soft and friable, lenticular beds of limonite

\section{Columner Section of Shonari member of Laki Formation from Lakhra area}

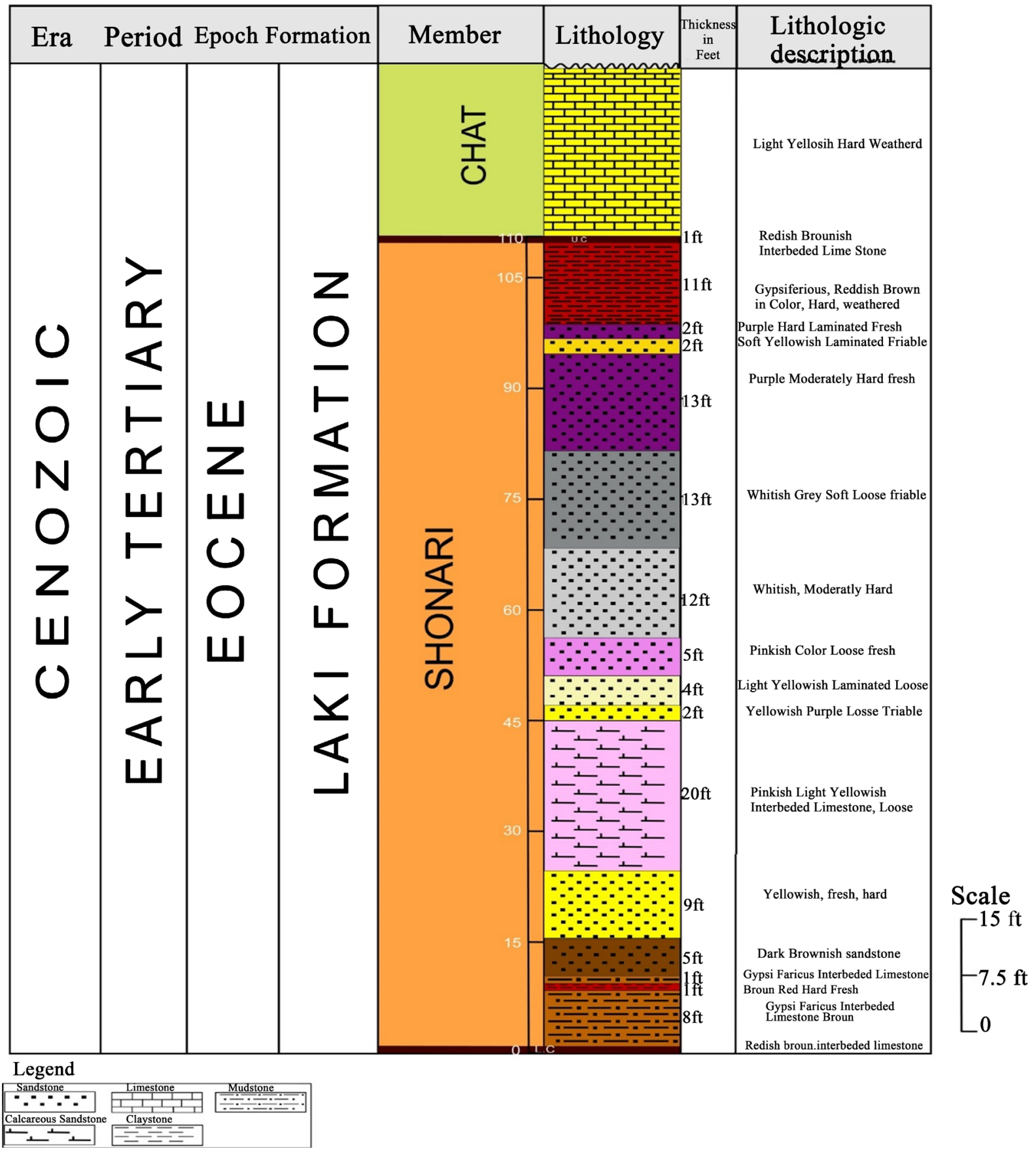

Figure 2. Colum section of the study area. 
ochre, white clay, (fire clay), and lignite coal seams.

\subsection{Stratigraphy of the Area}

The general stratigraphy of the study area is very much interesting in the research. The oldest stratigraphic unit is Bara Formation (Middle Paleocene age), [9]. The second oldest unit is Lakhra Formation (Late Paleocene). And the third one is the Laki Formation of the Eocene age. The fourth youngest stratigraphic unit is the Siwalik group i.e. Manchar Formation of (Mio-Pliocene age). General stratigraphy of the studied area is presented in (Table 1).

The second oldest stratigraphic unit of this area is the Lakhra Formation of (late Paleocene) age [2], Lakhra Formation was also proposed as a name for the "Upper Ranikot (limestone)" and "Upper Ranikot" of later workers, after Lakhra, Laki range [10]. The Formation is predominantly grey limestone with yellowish staining and weathering brown and buff, with some orange-brown and pinkish-brown patches. The lower section is made up of sandstone., with sand interbeds. In the upper section, there are sandstone and shale interbeds. The Bara Formation is uniformly overlain by the Formation. It is uncomfortably overlain by the Laki formation in the Kirthar province [2].

\subsection{Sohnari Member}

The thickness of the Sonhari member is about 25 feet [11]. SM is very well developed in the meeting Jhimpir area of Thatta district. The SM sometimes there are thin beds of sandy yellow limestone with assilina granulose. The thickness of the SM is varying from place to place (10 to 25 feet). SM is well developed in onger, mettign and Jampir areas. It is Lanticular, thickness varies from 1 to 20 meters. In the Lakhra area, the thickness ranges from 0 to 8 meters. The SM is missing in drill no L-25 and L-27 of the Lakhra area. Lenticular beds of limonite, ochre white clay (fire clay) and lignite coal seams of varying thickness or characteristic unit for the member and have also the commercial importance and The Ranikot and the Laki have interacted. There is a layer of ferogeneous claystone and siltstone that ranges from 17 to 19 feet thick and is known as laterite. It's a concrete color with sporadic white spots, and it's moderately strong (Figure 3). These lateritic beds are on the contact of the Formation are present in the Lakhra area [12]. The surface exposure of the Sohnari member consists of the highly ferruginous claystone and the sandstone of the variegated colors varies from yellowish-brown, rusty brown, dark yellowish, brown, white, cheery red, and

Table 1. Shows the Stratigraphy of the study area.

\begin{tabular}{cccc}
\hline S. No & Formation & Age & Lithology \\
\hline $\mathbf{1}$ & Siwalik group & Mio-Pliocene & Conglomerate, Sandstone and Clay \\
$\mathbf{2}$ & Laki Formation & Eocene & Limestone, shale and sandstone \\
$\mathbf{3}$ & Lakhra Formation & Late Paleocene & Limestone, shale and sandstone \\
$\mathbf{4}$ & Bara Formation & Middle Paleocene & Sandstone, Shale and shale \\
\hline
\end{tabular}


purple color. The Sandstone is fine to medium-grained [13]. Poorly sorted loose friable and the lansoide and ferruginous sandstone with white calcareous sandstone are common in this member. Sometimes sandstone occurs in lenticular beds of variegated colors. Vary colored lateritic clay, shale of variegated color including, yellow-orange, maroon, rusty brown, arenaceous limestone, packed limestone of ochre lignited. There are no fossils present in the Sohnari Member of the Laki Formation, which dates from the early Eocene.

The SM is the basal part of the Laki Formation which overlies the Ranikot group and the Lakhra Formation of the Lakhra area [14]. It has an uncomfortably marked basal contact with the Ranikot group and an upper contact with the Chat member of the Laki Formation. The Sohnari member of the Laki Formation is also thought to be distinct from the underlying Lakhra Formation and the overlying Chat member (Figure 3).

\section{Material \& Methods}

The detailed geological fieldwork was carried out and rock samples were collected for the study, one section of Sohnari member was measured from the eastern flank of the Lakhra anticline. The elemental analysis of the sample was accomplished by (SEM \& EDS), a total of fifteen samples was collected according to the bedding of the Formation.

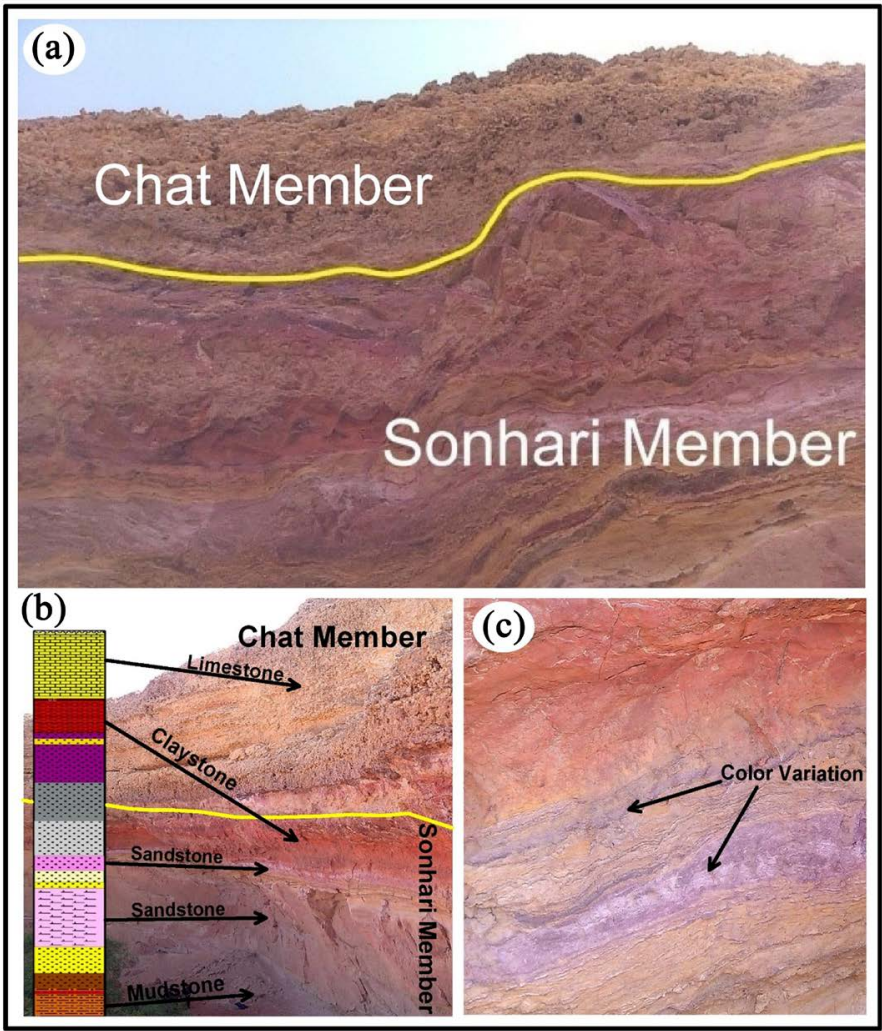

Figure 3. (a) Image showing the contact between Sohnari member and Chat Member. (b) The lithological log shows the Lithostratigraphic units of study area. (c) Image showing the color variation within beds of study area. 


\subsection{Geological Fieldwork}

The section of Sohnari Member of Laki Formation was measured, latitude $25^{\circ} 40^{\prime} 00^{\prime \prime} \mathrm{N}$ and longitude Long; $\left.68^{\circ} 5^{\prime} 00^{\prime \prime} \mathrm{E}\right)$. Geological hammer, Brunton compass, measuring tape, sample bags, permanent marker, hand lenses were used during field at Sohnari Member of Laki Formation. During geological fieldwork, we have observed primary sedimentary structures i.e. (cross-bedding, lamination, and ripples) and massive beds of outcrops, and Photographed.

\subsection{Sampling}

These samples enclosed sandstone, nodular limestone and lateritic clay, and gypsiferous shale of variegated colors including yellow, orange, red, maroon, rusty brown, and gray. Sandstones of Sohnari Member of Laki Formation vary in Brown (dark brown to light brown) yellowish, light yellow, white, pinkish, and purple colors. These sandstones are loose and consolidated. Clay of Sohnari Member of Laki Formation varies in radish brown and dark brown colors. Sampling was done according to the bedding in Sohnari Member of Laki Formation. The loose and unconsolidated sandstones of the studied stratigraphic unit are selected for Lab analysis.

\section{Result}

Six rock samples from the Sohnari member were collected, prepared, and analyzed by the Advance Research Laboratory of the Centre for Pure and Applied Geology, University of Sindh, Jamshoro. Energy-dispersive x-ray spectroscopy (EDS) is a technique for analyzing elements and determining the chemical properties of a sample form of XRF [15] and [16]. It is a form of spectroscopy that involves analyzing a sample by interactions between electromagnetic radiation and matter, such as detecting X-rays imitated by matter in response to being struck with charged particles [17]. Its classification abilities are due in large part to the general premise that each element has a unique atomic structure, which enables X-rays that are products of an element's atomic structure to be differentiated from one another is centered into the sample being analyzed to induce the release of distinctive X-rays (Figure 4). When an atom in a sample is at rest, it includes ground state (or unexcited) electrons in distinct energy ranges or electron shells, which are expelled from the shell, leaving an electron-hole in its place. An electron released from an exterior, higher-energy shell, and a lower-energy shell in the shape of a specimen can be quantified with an energy dispersive spectrometer.

The elemental composition of the specimen can be measured since $\mathrm{x}$-ray radiation is a result of the temperature differential between the two shells as well as the atomic structure of the elements from which it was emitted.

\section{Discussion}

\section{Silicon $\left(\mathrm{SiO}_{2}\right)$ :}

The silicon dioxide content of the sediments analyses ranges from $19.25 \%$ to 

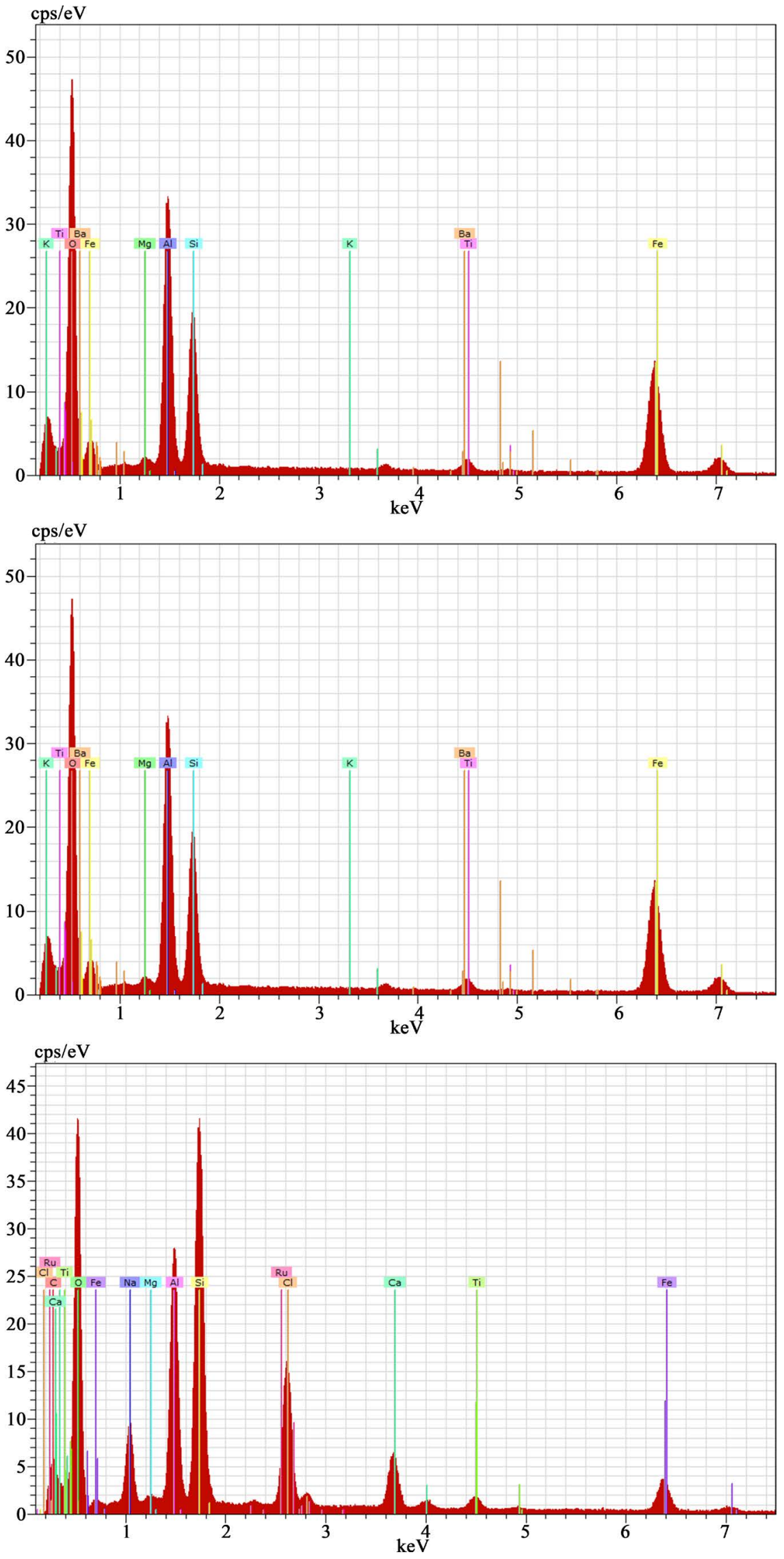

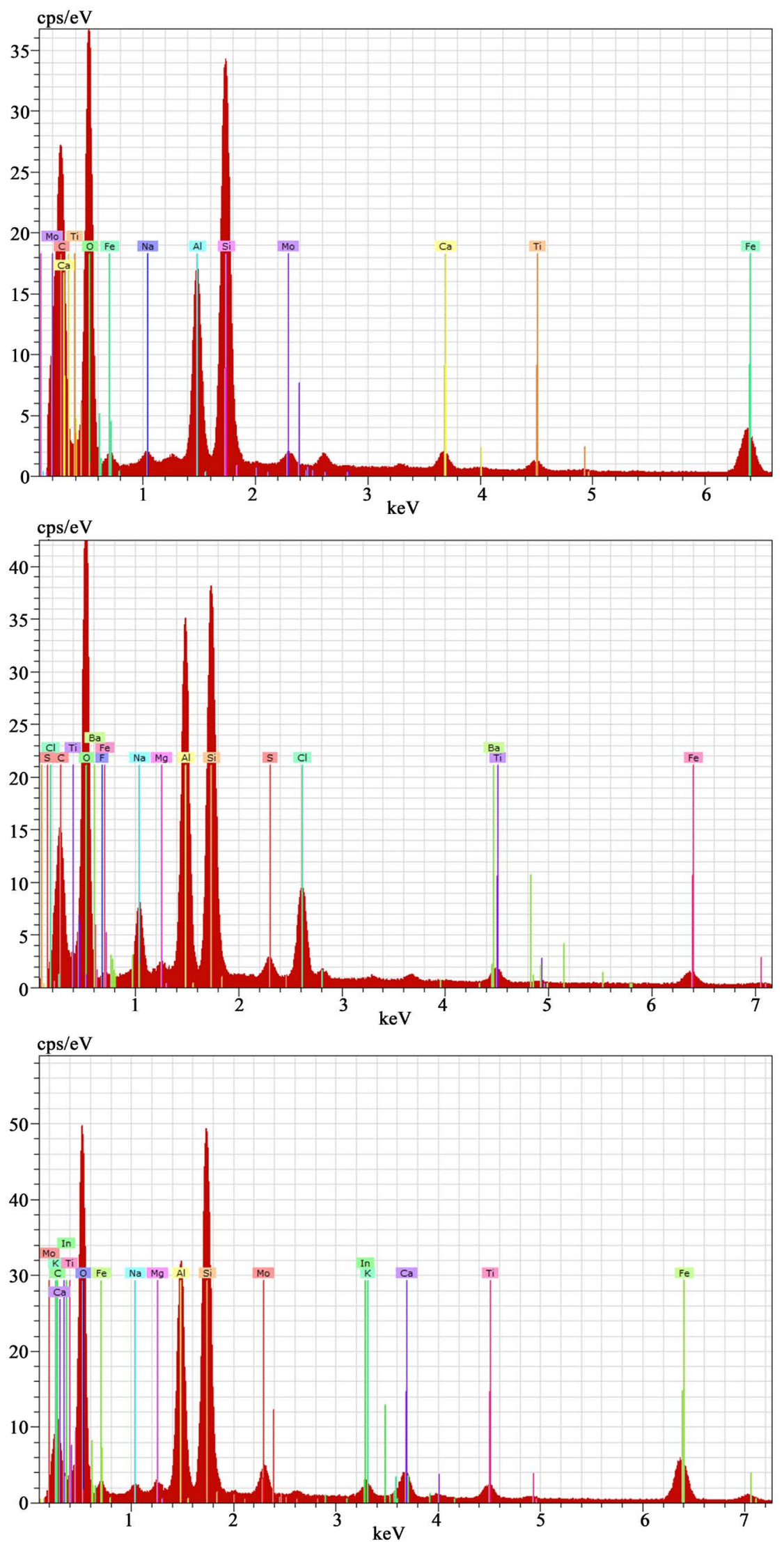

Figure 4. Shows the EDS analysis of the study area. 
$32.83 \%$, with an average of $24.54 \%$, in $(n=6)$ samples (Table S1). Si/Al ratios are used by sedimentary geochemists to determine the presence of various forms of silica in sedimentary rocks [18]. Couture made use of the Si/Al scale in sedimentary rocks for the measurement of bigamous Silica, indicated that a higher $\mathrm{Si} / \mathrm{Al}$ value indicates the $\mathrm{A}$ higher $\mathrm{Si} / \mathrm{Al}$ value indicates the presence of bigamous silica, while a lower $\mathrm{Si} / \mathrm{Al}$ value indicates the presence of terrigenous material. The Si/Al amount of the surveyed sediments varies from (0.59) to (1.94), with an average of (1.27), as seen in the graph (Table S2). The presence of biogenically precipitated Silica and detrital Silica is indicated by the highest and lowest values in the observed sediments, respectively.

\section{Titanium $\left(\mathrm{TiO}_{2}\right)$ :}

The titanium dioxide content of the analyzed $(\mathrm{N}=6)$ samples ranges from $1.25 \%$ to $3.10 \%$, with an average of $8.37 \%$. The majority of $\mathrm{Ti} / \mathrm{Al}$ ratios in the studied samples indicate that the Sohnari member of the Laki Formation is made up of sandstone, confirming previous research. Furthermore, [19] used the ( $\mathrm{Ti} / \mathrm{Al}$ ) ratio to complete the Transition in Temperature during Deposition, and the interpretation of the $(\mathrm{Ti} / \mathrm{Al})$ ratio indicates that the Sample region witnessed shifting Climatic conditions during Sediment Deposition.

\section{Aluminum $\left(\mathrm{Al}_{2} \mathrm{O}_{3}\right)$ :}

The Aluminum trioxide of Sohnari member of Laki Formation Sediments (N $=6$ ) varies (Table S1), from (11.12\%) to (32.25\%) with an average of $(21.28 \%)$. Kaolinite and illite hold high concentrations [20]. Kaolinite, chlorite, illite, and Montmorillonite Clay minerals are present in Sohnari members of the Laki Formation. The maturity index of the analyses rock samples was determined using the $\mathrm{Al}_{2} \mathrm{O}_{3} / \mathrm{Na}_{2} \mathrm{O}_{3}$ ratio, as suggested by [21] and [22]. The $\mathrm{Al}_{2} \mathrm{O}_{3} / \mathrm{Na}_{2} \mathrm{O}$ ratios (6.62 to 20.80) mean that the sediments analyzed are younger and are shipped as detrital particles. The $\mathrm{Al}_{2} \mathrm{O}_{3} / \mathrm{SiO}_{2}$ ratio of the analyzed rock samples, suggests that sediments of Sohnari member of the Laki Formation do not contain a substantial amount of minerals found in clay (Table S2).

\section{Iron $\left(\mathrm{Fe}_{2} \underline{\mathrm{O}}_{3}\right)$ :}

The iron concentration in Sohnari member samples studied $(\mathrm{N}=6)$ ranges from $2.75 \%$ to $37.54 \%$, with an average of $2.75 \%$ to $16.17 \%$ ). To determine the relationship between iron and clay minerals, the $\mathrm{Fe}_{2} \mathrm{O}_{3} / \mathrm{Al}_{2} \mathrm{O}_{3}$ ratio is used [23] and [24]. The $\mathrm{Fe}_{2} \mathrm{O}_{3} / \mathrm{Al}_{2} \mathrm{O}_{3}$ ratios of the samples analyzed show a poor association with clay minerals (Table S2). The Mn/Fe ratio has been used to classify depositional conditions in sedimentary rocks [25] and [26]. The observed $\mathrm{Mn} / \mathrm{Fe}$ ratios indicate that the Sohnari member of the Laki Formation was deposited nearshore to offshore. The Low $\mathrm{Mn} / \mathrm{Fe}$ ratio is a consequence of this leaching process. Strong chemical weathering can cause a high concentration of $\mathrm{Fe}_{2} \mathrm{O}_{3}$ to develop [27].

\section{Magnesium (MgO):}

The $\mathrm{mg} / \mathrm{Al}_{2} \mathrm{O}_{3}$ ratio measured from the $\mathrm{MgO}$ distribution in the analyzed $(\mathrm{N}=$ 6) samples ranges from $0.92 \%$ to $1.65 \%$, (Table S1), with mean values of $(1.05 \%)$. 
[23] for the presence of Montmorillonite and Clay minerals, and the $\mathrm{mg} / \mathrm{Al}_{2} \mathrm{O}_{3}$ ratio calculated according to [24] for the presence of Montmorillonite and Clay minerals, and the $\mathrm{mg} / \mathrm{Al}_{2} \mathrm{O}_{3}$ (Table S2). The occurrence of $\mathrm{MgO}$ in montmorillonite lattices is suggested by its weak positive correlation with iron.

\section{Sodium $\left(\mathrm{Na}_{2} \mathrm{O}\right)$ :}

The concentration of $\left(\mathrm{Na}_{2} \mathrm{O}\right)$ in the Sohnari member of the Laki Formation ranges from $1.79 \%$ to $7.85 \%$, with a mean of $3.61 \%(n=51)$ samples (Table S1). In contrast to other cations including $\mathrm{Ca}^{2+}$ and $\mathrm{Mg}^{2+}$, the montmorillonite (smectite) produces fewer $\mathrm{Na}+$ in the inter-layered position [20] and [25] used the $\mathrm{Na} / \mathrm{K}$ ratio to calculate the sediment deposition rate. These $\mathrm{Na} / \mathrm{K}$ ratios suggest a medium to high rate of sediment deposition in the samples analyzed.

\section{Potassium $\left(\mathrm{K}_{2} \mathrm{O}\right)$ :}

The Sohnari member of the Laki Formation $\left(\mathrm{K}_{2} \mathrm{O}\right)$ concentration ranges from $0.51 \%$ to $0.80 \%$, with a mean value of $0.51 \%$ and $0.21 \%$. As compared to other cations (calcium and magnesium), the lattices of montmorillonite often contain small amounts of potassium and sodium oxides [20], and [28] used the $\mathrm{Na} / \mathrm{K} \mathrm{ra}$ tio to calculate the rate of sediment deposition and the crystallinity of Illite. The presence of depleted illite and a low to high rate of sediment deposition was demonstrated by the $\mathrm{Na} / \mathrm{K}$ ratios of the examined samples. The $\mathrm{K}_{2} \mathrm{O} / \mathrm{Al}_{2} \mathrm{O}_{3}$ ratio is used to determine the amount of sand in a sediment sample [24], the density of sand in sediments, and the fast rate of sediment deposition was suggested by the $\mathrm{K}_{2} \mathrm{O} / \mathrm{Al}_{2} \mathrm{O}_{3}$ ratio of the samples analyzed.

\section{Sulphur (S):}

The sulphur concentrations range from $0.72 \%$ to $0.52 \%$, with an average value of $0.52 \%$ and $0.37 \%$ (Table S1). Sulfur content of shales is on average below $1 \%$. (0.25\%), the average concentration of European Paleozoic shales is 0.32\% [29] and [30]. The Sohnari member of the Laki Formation Sulphur in the samples indicates the presence of metabolizable organic matter, sulfate-reducing bacteria, and dissolved sulphide in the depositional conditions. [31] knows that the presence of sulphides in some Pacific Ocean trenches is due to a heavy content of organic matter and a high rate of sediment deposition. The Sohnari member of the Laki Formation sediments' rapid deposition rate may have resulted in reducing conditions during deposition, which may explain the presence of sulphur in the studied samples.

\section{Conclusions}

The Sohnari Laki Formation member is mostly quartz (low), with biogenically precipitated or detrital silica as the source of the silica. The Ti/Al ratio indicates that during the deposition of the Sohnari member of the Laki Formation sediments, the study region was subjected to shifting climatic conditions. The sediments under examination are younger and are shipped as detrital particles. The deposition rate is medium to high, and there is degraded illite in the samples. A sand abundance of sediments implies a high rate of deposition. Sulfur means 
that there is enough metabolizable organic matter available, reducing the depositional condition.

The Sohnari Laki Formation member was deposited under the fluvio-deltaic depositional scheme, based on its dominant quartz mineral composition, material ratios, and lower maturity. In the light of geochemical results, the sediments of Sohnari members composed of detrital Silica deposited in changing climatic conditions and medium to high rate of deposition, less mature, sufficient availability of metabolized of origin matter. It is concluded here these sediments are deposited under fluviotile conditions/origin.

\section{Acknowledgements}

This study was financially supported by the National Nature Science Foundation of China Grant, Prof. Dr. Huafeng Tang, and the Chinese Scholarship Council to Muhammad Asif Noonari to pursue the Master's Degree at College of Earth Science Jilin University of China. Furthermore, the auothers are thankful to Ex-Director of Centre Pure and Applied Geology University of Sindh Jamshoro Sindh, Prof. Dr. Sarfarz Hussain Solangi for providing the transport facility and moral support to carry out this study.

\section{Conflicts of Interest}

The authors declare no conflicts of interest regarding the publication of this paper.

\section{References}

[1] Outerbridge, W.F. and Khan, R.A. (1988) The Lakhra Anticline of Southern Pakistan Is Active. Geological Society of America Abstracts with Programs, 20, A149.

[2] Shah. S.M.I. (2009) Stratigraphy of Pakistan. Vol. 22, The Geological Survey of Pakistan, Islamabad.

[3] Kazmi, A.H. and Rana, R.A. (1982) Tectonic Map of Pakistan, Scale 1:2000000. Geological Survey of Pakistan Map Series, Quetta.

[4] Mangi, J., et al. (2020) Wood of Burseroxylon Fossil from Bara Formation of RaniKot Fort Area, District Jamshoro Sindh, and Pakistan: Institute of Plant Sciences, University of Sindh, and Jamshoro, Pakistan. Pakistan Journal of Agriculture, Agricultural Engineering and Veterinary Sciences, 36, 1-7. https://doi.org/10.47432/2020.36.1.1

[5] Blanford, W.T. (1872) Note on the Geological Formations Seen Ale the Coasts of Baluchistan and Persia, from Karachi to the Head of Persian Gulf and So of the Gulf Islands. Records of the Geological Survey of India, 5, 41-45.

[6] Vredenburg, E.W. (1906) The Classification of the Tertiary System in Sind Regarding the Zonal Distribution of the Eocene Echinoidea Described by Duncan and Sladen. Records of the Geological Survey of India, 34, 172-198.

[7] Hakro, A.A.D. and Baig, M.A.A. (2014) Depositional Environments of the Bara Formation Sandstones from Lakhra Areas Sindh, Pakistan. Pakistan Journal of Scientific and Industrial Research, 57, 20-31. https://doi.org/10.52763/PJSIR.PHYS.SCI.57.1.2014.20.31 
[8] Fatmi, A.N. and Sbeta, A.M. (1991) The Significance of the Occurrence of Abu Ghaylan and Kiklah Formations East of Wadi Ghan, Eastern Jabal Nafusah. In: Salem, M.J. and Bakbak, M.R., Eds., The Geology of Libya, Volume III, Academic Press, London, 2227-2233.

[9] Wnuk, C., SanFilipo, J., Fatmi, F. and Fariduddin, M. (1991) The Stratigraphy and Coal Resource Potential of the Sohnari Member of the Laki Formation in Sindh Province, Pakistan; a Progress Report. US Geological Survey. https://doi.org/10.3133/ofr91326

[10] Malkani Sadiq, M., et al. (2017) Mineral Resources of Sindh, Pakistan. Geological Survey of Pakistan, Information Release No. 994, 1-38.

[11] Acquafredda, P., et al. (1999) Chemical Characterization of Obsidians from Different Mediterranean Sources by Non-Destructive SEM-EDS Analytical Method. Journal of Archaeological Science, 26, 315-325.

https://doi.org/10.1006/jasc.1998.0372

[12] Agheem, M.H., et al. (2020) Mineralogical Studies of Manchar Formation (Pliocene) Laki Range, Pakistan: Source and Possible Occurrence of Bauxite. Sindh University Research Journal-SURJ (Science Series), 52, 30-40. https://doi.org/10.26692/SURJ/2020.03.04

[13] Siddiqui, I., Shah, M.T. and Ahmed, I. (2009) X-Ray Diffraction (XRD) Analyses of Thar, Sonda and Meting-Jhimpir Coalfields, Sindh. Sindh University Research Journal-SURJ (Science Series), p. 41.

[14] Siever, R. (1962) Silica Solubility, $0^{\circ} \mathrm{C}-200^{\circ} \mathrm{C}$, and the Diagenesis of Siliceous Sediments. The Journal of Geology, 70, 127-150. https://doi.org/10.1086/626804

[15] Pollard, C.O. and Weaver, C.E. (1973) Opaline Spheres; Loosely-Packed Aggregates from Silica Nodule in Diatomaceous Miocene Fuller's Earth. Journal of Sedimentary Research, 43, 1072-1076. https://doi.org/10.1306/74D728F6-2B21-11D7-8648000102C1865D

[16] Potter, P.E. and Pettijohn, F.J. (2012) Paleocurrents and Basin Analysis. Springer Science \& Business Media, Berlin.

[17] Pettijohn, F.J. (1957) Sedimentary Rocks. 2nd Edition, Harper, New York.

[18] Curtis, C.D. and Spears, D.A. (1968) The Formation of Sedimentary Iron Minerals. Economic Geology, 63, 257-270. https://doi.org/10.2113/gsecongeo.63.3.257

[19] Calvert, S.E. and Pedersen, T.F. (1993) Geochemistry of Recent Oxic and Anoxic Marine Sediments: Implications for the Geological Record. Marine Geology, 113, 67-88. https://doi.org/10.1016/0025-3227(93)90150-T

[20] Nicholls, G.D. and Loring, D.H. (1960) Some Chemical Data on British Carboniferous Sediments and Their Relationship to the Clay Mineralogy of These Rocks. Clay Minerals Bulletin, 4, 196-207. https://doi.org/10.1180/claymin.1960.004.24.05

[21] Hakro, A. and Baig, M. (2013) Depositional Environment of the Bara Formation, Fort Ranikot Area, Sindh. Sindh University Research Journal-SURJ(Science Series), 45, 83-94.

[22] Baig, M.A.A., Abro, A.R., Pathan, M.A., Ansari, Q. and Saghir, A. (1997) Geochemical and Mineralogical Investigation of Tiyon Formation from Surjan Anticline, Thanu Bula Khan, District Dadu, Sindh. Geological Bulletin University of Peshawar, 30, 153-164.

[23] Thomas, R.L. (1969) A Note on the Relationship of Grain Size, Clay Content, Quartz and Organic Carbon in Some Lake Erie and Lake Ontario Sediments. Journal of Sedimentary Research, 39, 803-809. 
https://doi.org/10.1306/74D71D34-2B21-11D7-8648000102C1865D

[24] Krauskopf, K.B. (1979) Current Perspectives in Geologic Disposal of Radioactive Wastes. Proceedings of the Symposium on Waste Management, 45, 83-94.

[25] Outerbridge, W.F., et al. (1989) The Sohnari Formation in southern Pakistan. US Geological Survey Bulletin, 17-34.

[26] Brohi, I.A., et al. (2012) Geological and Stratigraphical Studies of Dimension and Cut Stone Deposits around Khanu Brohi and Khadhar Areas, District Jamshoro, Sindh. Pakistan. Sindh University Research Journal-SURJ (Science Series), 44, 581-586.

[27] Hakro, A.D., et al. (2016) Depositional Environment of Sohnari Member Sandstone of Laki Formation from Southern Indus Basin, Pakistan. Sindh University Research Journal-SURJ (Science Series), 48, 227-232.

[28] Hakro, A., et al. (2018) Provenance and Tectonic Setting of Early Eocene Sohnari M Ember of Laki Formation from Southern Indus Basin of Pakistan. Geological Journal, 53, 1854-1870. https://doi.org/10.1002/gj.3011

[29] Migdisov, A.A., et al. (1980) 32. Major and Minor Elements and Sulfur Isotopes of the Mesozoic and Cenozoic Sediments at Sites 415 and 416, Leg 50, Deep Sea Drilling Project, 675-691. https://doi.org/10.2973/dsdp.proc.50.132.1980

[30] Shishkina, O.V. (1964) Chemical Diagenesis in Sediments. Chemical Oceanography, 6, 44 .

[31] Siddiqui, I., Agheem, M.H. and Soomro, A.S. (2012) Geochemistry and Mineralogy of Meting-Jhimpir Coal, Sindh, Pakistan. Mehran University Research Journal of Engineering \& Technology, 31, 281-290. 


\section{Appendix Tables}

Table S1. Major elements of study area.

\begin{tabular}{ccccccccccc}
\hline Sample & $\mathrm{Sio}_{2}$ & $\mathrm{TiO}$ & $\mathrm{Al}_{2} \mathrm{O}_{3}$ & $\mathrm{Fe}_{2} \mathrm{O}_{3}$ & $\mathrm{MgO}$ & $\mathrm{Ca}_{2}$ & $\mathrm{Na}_{2} \mathrm{O}$ & $\mathrm{K}_{2} \mathrm{O}$ & $\mathrm{SO}_{3}$ & Total \\
\hline $1 \mathrm{Ra}$ & 19.25 & 1.55 & 32.25 & 37.54 & 1.65 & - & - & 0.51 & - & 92.75 \\
$3 \mathrm{Ra}$ & 21.86 & 1.68 & 24.01 & 28.36 & 1.47 & 2.44 & 5.13 & - & 0.72 & 85.67 \\
$5 \mathrm{Ra}$ & 29.22 & 2.03 & 19.63 & 7.14 & 0.96 & 5.19 & 7.85 & - & - & 72.02 \\
$6 \mathrm{Ra}$ & 21.62 & 1.35 & 11.12 & 8.39 & - & 1.42 & 1.79 & - & - & 45.69 \\
$10 \mathrm{Ra}$ & 22.48 & 1.25 & 19.83 & 2.75 & 0.92 & - & 4.97 & - & 1.52 & 53.72 \\
$11 \mathrm{Ra}$ & 32.83 & 3.10 & 20.55 & 12.86 & 1.32 & 3.00 & 1.94 & 0.80 & - & 76.4 \\
Minimum & 19.25 & 1.25 & 11.12 & 2.75 & 0.92 & 1.42 & 1.79 & 0.51 & 0.72 & - \\
Maximum & 32.83 & 3.10 & 32.25 & 37.54 & 1.65 & 5.19 & 7.85 & 0.80 & 1.52 & - \\
Average & 24.54 & 1.82 & 21.23 & 16.17 & 1.05 & 2.00 & 3.61 & $\mathbf{0 . 2 1}$ & $\mathbf{0 . 3 7}$ & - \\
\hline
\end{tabular}

Table S2. Ratios of elements of samples from Sohnari member of Laki formation.

\begin{tabular}{ccccccccc}
\hline Sample & $\begin{array}{c}\mathrm{Al}_{2} \mathrm{O}_{3} / \\
\mathrm{SiO}_{2}\end{array}$ & $\begin{array}{c}\mathrm{Al}_{2} \mathrm{O}_{3} / \\
\mathrm{Na}_{2} \mathrm{O}\end{array}$ & $\begin{array}{c}\mathrm{Fe}_{2} \mathrm{O}_{3} / \\
\mathrm{Al}_{2} \mathrm{O}_{3}\end{array}$ & $\begin{array}{c}\mathrm{K}_{2} \mathrm{O} / \\
\mathrm{Al}_{2} \mathrm{O}_{3}\end{array}$ & $\begin{array}{c}\mathrm{MgO} / \\
\mathrm{Al}_{2} \mathrm{O}_{3}\end{array}$ & $\begin{array}{c}\mathrm{SiO}_{2} / \\
\mathrm{Al}_{2} \mathrm{O}_{3}\end{array}$ & $\begin{array}{c}\mathrm{Na}_{2} \mathrm{O} / \\
\mathrm{K}_{2} \mathrm{O}\end{array}$ & $\begin{array}{c}\mathrm{TiO}_{2} / \\
\mathrm{Al}_{2} \mathrm{O}_{3}\end{array}$ \\
\hline $1 \mathrm{Ra}$ & 0.59 & 32.25 & 1.16 & 0.01 & 0.05 & 0.59 & 0.51 & 0.04 \\
$3 \mathrm{Ra}$ & 0.91 & 4.68 & 1.18 & 24.01 & 0.06 & 0.91 & 5.13 & 0.06 \\
$5 \mathrm{Ra}$ & 1.48 & 2.50 & 0.36 & 19.63 & 0.04 & 1.48 & 7.85 & 0.10 \\
$6 \mathrm{Ra}$ & 1.94 & 6.21 & 0.75 & 11.12 & 11.12 & 1.94 & 1.79 & 0.12 \\
$10 \mathrm{Ra}$ & 1.13 & 3.98 & 0.13 & 19.83 & 0.04 & 1.13 & 4.97 & 0.06 \\
$11 \mathrm{Ra}$ & 1.59 & 10.59 & 0.62 & 20.55 & 0.06 & 1.59 & 2.42 & 0.15 \\
Average & 1.27 & 10.03 & 0.7 & 15.85 & 1.89 & 1.27 & 3.77 & $\mathbf{0 . 0 8}$ \\
\hline
\end{tabular}

